BMJ Open

Diabetes

Research

\& Care

\title{
Detection of C-peptide in human hair and nail: a comparison between healthy persons and persons with type 1 diabetes
}

\author{
Jamal M Salih, Darya S Abdulateef (D)
}

To cite: Salih JM, Abdulateef DS. Detection of $\mathrm{C}$-peptide in human hair and nail: a comparison between healthy persons and persons with type 1 diabetes. BMJ Open Diab Res Care 2020;8:e001297. doi:10.1136/ bmjdrc-2020-001297

Received 24 February 2020 Revised 11 June 2020 Accepted 16 June 2020
Check for updates

\section{C) Author(s) (or their} employer(s)) 2020. Re-use permitted under CC BY-NC. No commercial re-use. See rights and permissions. Published by BMJ.

Physiology, University of Sulaimani College of Medicine, Sulaimani, Kurdistan, Iraq

Correspondence to Dr Darya S Abdulateef; darya.abdulateef@univsul. edu.iq

\section{ABSTRACT}

Objectives Serum and urinary C-peptide has clinical implications in people with/without diabetes. Recently, C-peptide was detected in hair samples of healthy adults but not studied in people with diabetes. It is not known whether C-peptide can be detectable in nail tissue or not. This study aims to assess the detection of C-peptide in hair and nail samples and to find whether hair and nail C-peptide levels are different in type 1 diabetes mellitus (T1DM) compared with healthy individuals.

Research design and methods In a prospective casecontrol study on 41 subjects with T1DM and 42 control subjects, hair and nail samples were collected and prepared. C-peptide was extracted by incubating the samples with methanol and measuring the extract with an immunoassay. The hair and nail $\mathrm{C}$-peptide values were compared between the T1DM and control group and their correlations with each other and with other variables were assessed with a significant level set at 0.05 .

Results Hair and nail C-peptide levels were detected in both groups, with significantly lower values in T1DM compared with the control group. T1DM with >7-year diabetes duration had significantly lower C-peptide in serum, nails and hair. Hair and nail C-peptide levels have significant positive correlations with each other and negative correlations with age.

Conclusions We conclude that C-peptide are detectable in the hair and nails of healthy persons and persons with T1DM. Compared with the healthy persons, persons with T1DM had significantly lower hair and nail C-peptide and significant hair/nail C-peptide reduction after 7 years of diagnosis. Our results suggest that hair and nails are suitable matrices for the measurement of $\mathrm{C}$-peptide in healthy persons and persons with T1DM.

\section{INTRODUCTION}

The pancreatic $\beta$-cells secrete insulin and connection peptide (C-peptide). ${ }^{1}$ Previous studies recommended C-peptide measurement as an accurate indicator of the amount of endogenous insulin secretion since both insulin and C-peptide are secreted in equimolar amounts and the latter has a longer half-life. ${ }^{1-3}$ C-peptide has important clinical

\section{Significance of this study}

What is already known about this subject?

- Serum or urinary C-peptide represents endogenous insulin secretion; it has clinical importance in people with or without diabetes.

- Recently, C-peptide have been detected in hair samples of normal adults.

What are the new findings?

- C-peptide is detectable in both hair and nail matrices of healthy people and and people with type 1 diabetes mellitus (T1DM).

- Hair/Nail C-peptide was significantly lower in T1DM compared with healthy people.

- Hair/Nail C-peptide was also lower in T1DM with > 7year diabetes compared with shorter duration of the disease.

- Hair and nail C-peptide showed a significantly strong correlation with each other.

How might these results change the focus of research or clinical practice?

- Hair and nail C-peptide may represent stable and long-term endogenous insulin secretion compared with that of serum or urine.

- If hair/nail C-peptide measurement is validated, it can be helpful in the management plan of people with diabetes and assess the insulin requirement.

- Moreover, hair/nail C-peptide may better figure out the associations between insulin resistance and relevant diseases.

implications and a high C-peptide level, which may be a sign of insulin resistance (IR), is shown to be associated with increased morbidity and mortality. ${ }^{4-8}$ Particularly in people with diabetes, C-peptide is useful to differentiate the types of diabetes and also helps to introduce a proper management strategy. ${ }^{9}$ Moreover, a low level of C-peptide has been linked to an increased risk of diabetes complications. ${ }^{10}$

The pathophysiology of type 2 diabetes mellitus (T2DM) includes IR and 
relative insulin deficiency, whereas type 1 diabetes mellitus (T1DM) results from pancreatic $\beta$-cell destruction and subsequent insulin deficiency. ${ }^{11}{ }^{12}$ Meanwhile, some of the $\beta$-cells may be preserved to secrete small amounts of insulin even years after the diagnosis. ${ }^{13}$

Previous researches have measured C-peptide in blood and/or urine samples when the person has fasted, fed or had stimulation tests. ${ }^{14-16}$ Blood or urine C-peptide should be interpreted with the concomitant blood glucose concentration as it can be hugely affected by the concurrent glycemia. Moreover, the renal excretory function should be addressed, especially when a urine sample is used since urine C-peptide can be substantially affected by the rate of renal functioning. ${ }^{917}$ Multiple blood sampling, glucagon-induced nausea or 24 hours urine collection can be inconvenient and time-consuming to patients; however, second void urine spot sampling appears to be practical. Additionally, there was a gender difference in the level of urinary C-peptide. ${ }^{18}$ Serum and urine samples must be put directly on ice and need special storage, respectively, until they reach the laboratories where they can be measured.

Since the last decade, steroid hormones were extracted from hair and nail specimens. ${ }^{19-23}$ This is of interest, particularly for substances which are secreted in an unsteady manner like cortisol and insulin/C-peptide. ${ }^{1922} 23$ The hair growth rate is found to be around $1 \mathrm{~cm} / \mathrm{month}$, while nails grow about $3.47 \mathrm{~mm} /$ month. ${ }^{24-26}$ Therefore, by a single-time hair and/or nail samplings, researchers can get the retrospective values of the hormone exposure throughout the preceding months. Hair and nail samplings are easy and non-invasive. Besides, the samples can be transferred to the lab and stored at room temperature in a dark and dry place.

Very recently, a study has detected C-peptide in hair samples of those who are healthy. It also suggested that hair C-peptide may represent a long-term, rather than temporary, endogenous insulin secretion. In addition, the hair C-peptide level might correspond to both basal and prandial insulin secretion all together. ${ }^{27}$ This is of great importance when it is required to observe the link between a more stable, long-term insulin secretion and the relevant diseases.

To the best of our knowledge, there is no published study on hair C-peptide measurements in people with T1DM nor any published studies on nail samples that have been tested for C-peptide in both healthy persons and persons with T1DM. In this study, we compared hair and nail C-peptide levels between healthy people and subjects with T1DM.

The aims of this study were to observe whether hair C-peptide levels are lower in T1DM compared with healthy adults. Our further aim was to know whether C-peptide is detectable in human fingernail samples. The detectable nail C-peptide will be further compared with hair C-peptide levels in both healthy adults and people with T1DM.

\section{RESEARCH DESIGN AND METHODS}

\section{The studied subjects}

In a prospective case-control study, 83 (41 T1DM, 42 control) participants were recruited from January 2018 to December 2019. The cases included consecutive subjects with T1DM who visited the Diabetes Center Hospital at Sulaymaniyah in Iraq, who were willing to participate in the study. The control group included agematched healthy subjects at Oxford English Center and the College of Medicine who volunteer to participate in the study.

Any subject younger than 18 years were excluded from the study; the exclusion criteria also included subjects with other systemic diseases, recent acute illnesses and those on medication (apart from insulin for T1DM). Patients with T1DM with comorbidities, such as renal failure and uncontrolled thyroid diseases, were also excluded from the study.

All the cases and controls were assessed for the sociodemographic status. The detailed questionnaire filled it out to all participants, which included past medical and surgical history, family history of T2DM, together with the duration of diabetes and insulin dose (units $/ \mathrm{kg} /$ day) in subjects with T1DM. Height, weight and waist circumference were measured and recorded and the body mass index (BMI) was calculated.

\section{Blood sample collection}

The participants were asked to start fasting at 22:00 hours the day before blood sampling. Blood samples were received from all subjects. Fasting plasma glucose (FPG) was measured in all participants.

The subjects with T1DM were advised not to receive their morning insulin dose on the day of blood sampling. In the subjects with T1DM, serum C-peptide was measured using the Roche Diagnostics, Germany, and hemoglobin Alc (HbA1c) and FPG were measured with the use of COBAS c111 (HITACHI) by the absorbance photometry assay technique.

\section{Hair and nail sampling: extraction and assay procedure}

For hair C-peptide, the same hair sampling preparation and extraction procedure mentioned by Abdulateef $e t$ $a l$ were used. After a thorough description of the procedure on how to take the hair sample, a strand of hair was banded and cut at the most proximal portion to the scalp. The cut hair was put into an envelope and the proximal ends were marked. The hair samples were stored in a cool, dark and dry place until the analysis.

The participants were given a Ziploc bag and were instructed on how to clip their fingernails so that the clippings would fall straight into the bag to prevent the loss of any clipped nails. The nails were clipped from all fingers from both hands. If there were not enough nails present, the subjects were asked to visit again (after approximately 10 days) until the required amount of the nail had grown in order to be clipped and collected. 
The nail samples were washed two times with distilled water and an isopropanol solution $(99.5 \%)$ with $10 \mathrm{~s}$ of mixing each time. Then, the samples were dried and put into envelopes by the same storage condition of the hair sample. All envelopes with hair and nail samples were coded.

The hair and nail samples were cut into very small pieces $(1-2 \mathrm{~mm})$ with a surgical scissor, weighed on an electrical analytical balance and all weights were recorded. Any sample with less weight than the required sample of $20-60 \mathrm{mg}$ was not analyzed, and the subject data were excluded from the study.

After weighing the samples, they were placed into coded glass tubes with tight screw caps, and $1.6 \mathrm{~mL}$ of pure methanol (99\%) was added into each tube. The samples within methanol were incubated inside a shaking incubator for about 16 hours with a temperature of $50^{\circ} \mathrm{C}$. After incubation, the samples were centrifuged and $1 \mathrm{~mL}$ of supernatant was pipetted into another glass tube with the same code, using a micropipette.

The supernatant was left to dry at room temperature and the dried samples were mixed with a phosphate buffer saline solution with a $\mathrm{pH}$ of 8.2. The samples were mixed for $30 \mathrm{~s}$ on a mixer and then another $30 \mathrm{~s}$ of mixing were repeated to ensure the dried sample on the inner wall of the glass tube had completely dissolved

The samples were analyzed by the electrochemiluminescence immunoassay method, using a COBAS e411 analyzer from the Roche Diagnostic with the use of the same C-peptide serum kit in Germany.

The readings were recorded in $\mathrm{ng} / \mathrm{mL}$ and were converted to $\mu \mathrm{g} / \mathrm{dL}$, then the amount of C-peptide in hair/nail in $\mathrm{pg} / \mathrm{mg}$ of hair/nail sample were calculated using the equation used by Meyer et al. ${ }^{28}$

\section{Group description}

T1DM: this includes any subjects with established T1DM, according to the American Diabetes Association, without a honeymoon period and taking an insulin dose of $>0.5$ unit/ $\mathrm{kg} /$ day.

Control: this includes any subject without T1DM and other diseases.
The subjects with T1DM were divided into two groups according to the duration of T1DM: a group with a duration of T1DM of fewer than 7 years and a group with $>7$ years.

The subjects with or without T1DM were divided into two groups according to their family history of T2DM within their first-degree relatives: a group with positive family history and a group with negative family history.

\section{Statistical analysis}

The data entry and statistical analysis were performed using SPSS software. Normality tests were performed for all of the variables. Apart from weight, duration of diabetes and $\mathrm{HbAlc}$, all the variables are non-parametric. A descriptive statistic was done to find the mean and median of each variable with SD and range. The MannWhitney $\mathrm{U}$ test was used to compare the demographic and biochemical parameters between the T1DM and control group, while the Student's t-test was used for comparing nail, hair and serum C-peptide in T1DM within the two groups of different disease duration with the $p$ value set at 0.05 . Correlation between nail and hair C-peptide with FPG, age and other parameters were evaluated using Spearman's correlation. $\mathrm{P}$ value $<0.05$ was regarded as statistically significant.

\section{RESULTS}

A total of 83 subjects (41T1DM, 42 controls) were included in the analysis. The mean age was 20.8 with the range between 18 and 34 years. Among the participants were 39 females and 44 males. There were no significant differences in age, BMI or waist circumference between the T1DM and control group.

Mean hair C-peptide in control group was 107 (85.57) with the median of 78.65 (357.77) pg/mg hair. Median hair and nail C-peptide was significantly lower in subjects with T1DM compared with the control group with the $\mathrm{p}$ values $<0.001$ and 0.007 , respectively. There was significantly higher FPG in subjects with T1DM compared with the control group with the $p$ value $<0.001$, as shown in table 1 and figure 1.

\begin{tabular}{llcc}
\hline Table 1 & Comparison between T1DM and control in biochemical and demographic parameters & \\
\hline Variable & $\begin{array}{l}\text { Control } \\
\text { Median (range) } \mathbf{n}=\mathbf{4 2}\end{array}$ & $\begin{array}{l}\text { T1DM } \\
\text { Median (range) } \mathbf{n}=\mathbf{4 1}\end{array}$ & P value* $^{*}$ \\
\hline Age (years) & $18(15)$ & $18.5(16)$ & 0.226 \\
BMI $\left(\mathrm{kg} / \mathrm{m}^{2}\right)$ & $23.15(14.71)$ & $22.66(12.71)$ & 0.144 \\
Waist circumference (cm) & $78(32)$ & $74(28)$ & 0.09 \\
FPG (mg/dL) & $78.5(42)$ & $184(404)$ & $<0.001$ \\
Hair C-peptide (pg/mg hair) & $78.65(357.77)$ & $38.05(390.2)$ & $<\mathbf{0 . 0 0 1}$ \\
Nail C-peptide (pg/mg nail) & $32.49(100.72)$ & $24.78(40.57)$ & $\mathbf{0 . 0 0 7}$ \\
\hline
\end{tabular}

*Mann-Whitney $U$ test is used to compare the variables between the two groups and assessing significant. The significant $P$-value are demonstrated in bold.

BMI, body mass index; FPG, fasting plasma glucose; T1DM, type 1 diabetes mellitus. 


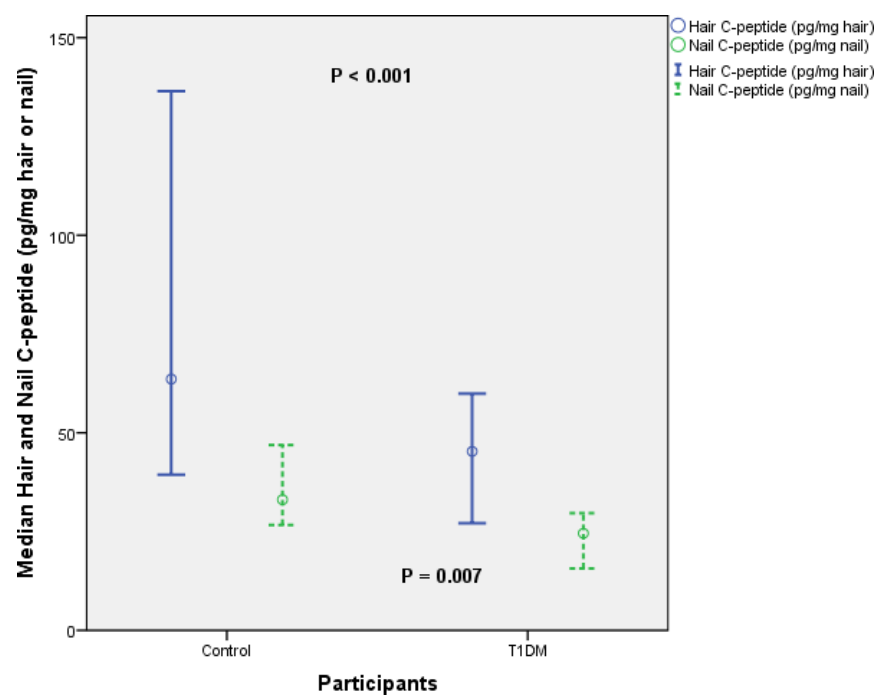

Figure 1 Comparison in hair and nail C-peptide level between type 1 diabetes mellitus (T1DM) and control group. The blue continuous line is hair C-peptide, the green dotted line is nail C-peptide.

There is no significant difference in the median hair and nail C-peptide levels between male and female subjects in the control group. The median hair C-peptide for male versus female of 84 (334.34) vs 64.41 (291.69) had a $\mathrm{p}$ value of 0.177 , while median nail C-peptide of male versus female was 31.31 (99.91) vs 34.09 (57.34) with a $p$ value of 0.967 .

Figure 2 illustrates a significantly higher nail and serum C-peptide levels in T1DM with a disease duration of fewer than 7 years compared with T1DM with a disease duration of $>7$ years with a $p$ value $<0.05$. Median nail C-peptide is 29.68 (40.58) vs 21.78 (22.72) with a $\mathrm{p}$ value 0.048 .

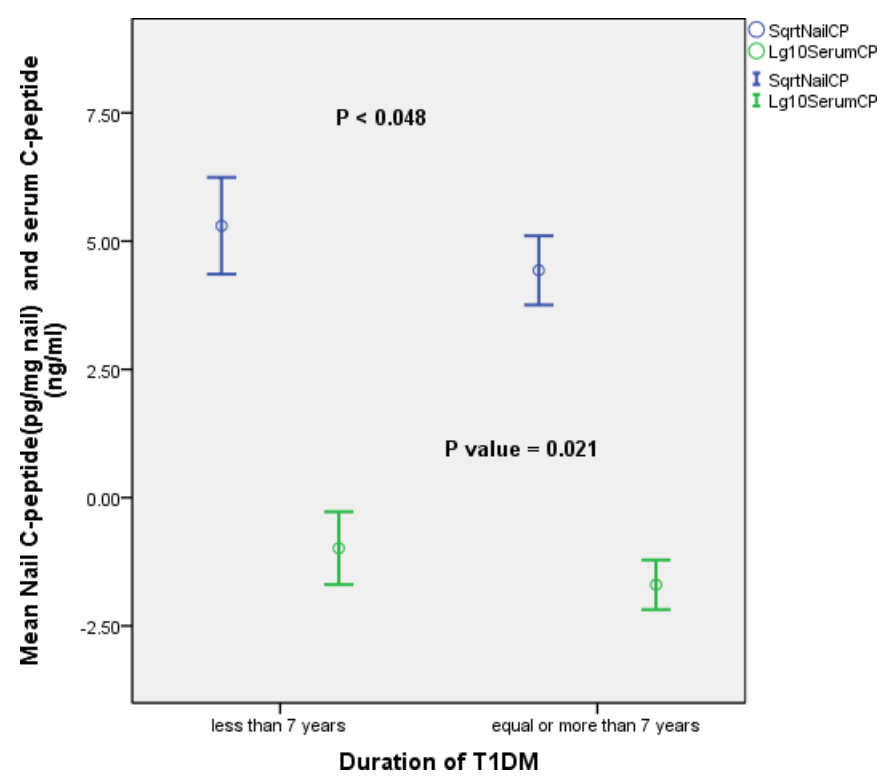

Figure 2 Differences in nail and serum C-peptide (CP) level in patients with type 1 diabetes mellitus (T1DM) according to different duration of the disease. The blue line is nail $\mathrm{CP}$, the green line is serum CP levels.

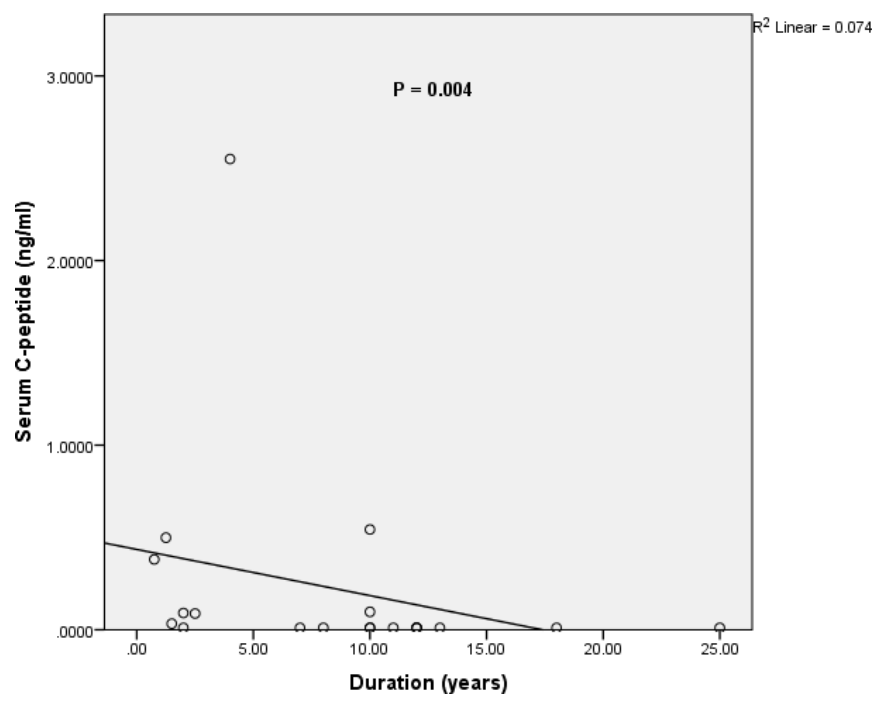

Figure 3 The significant negative correlation between serum C-peptide with the duration of type 1 diabetes mellitus.

A significant negative correlation between serum C-peptide and the duration of T1DM is shown in figure 3; $\mathrm{r}=-0.608, \mathrm{p}=0.004$.

Hair C-peptide has a significant positive correlation with nail C-peptide $(\mathrm{r}=0.499, \mathrm{p}=0.008)$, as shown in figure 4 .

Significant negative correlations were found between each hair and nail C-peptide levels with their sample weight in the control group $(\mathrm{r}=-0.359, \mathrm{p}=0.025$ and $\mathrm{r}=-0.595, \mathrm{p}=0.001$, respectively), and nail C-peptide and nail sample weight in T1DM $(\mathrm{r}=-0.510, \mathrm{p}=0.007)$.

Figure 5 revealed a significant negative correlation of nail C-peptide with the age; $r=-0.409, p=0.025$, while positive correlation with the BMI; $r=0.399, p=0.035$, of studied participants in the control group. A significantly negative correlation between the age of control participants and hair C-peptide was found $(\mathrm{r}=-0.404, \mathrm{p}=0.011)$,

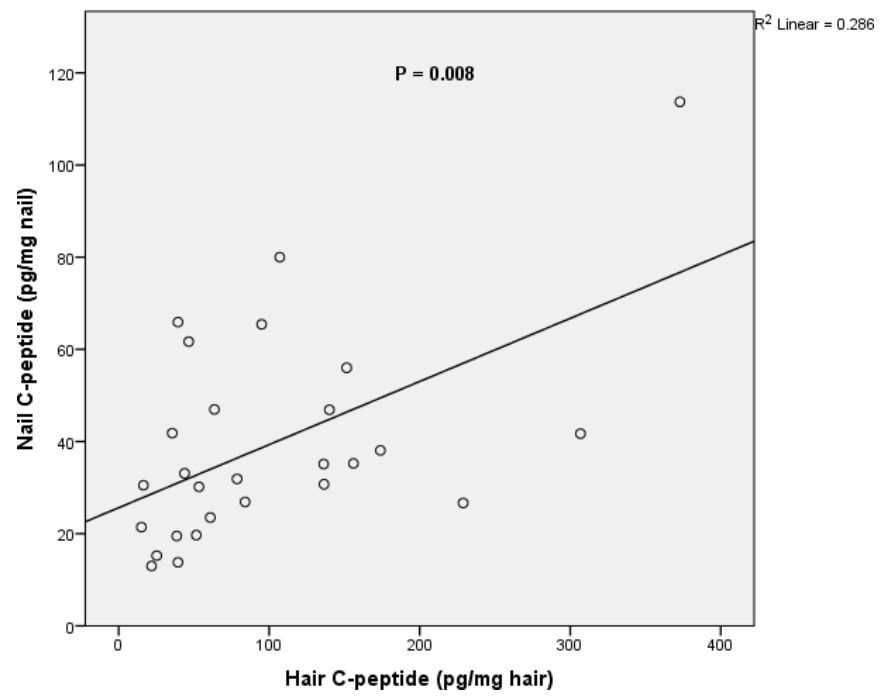

Figure 4 Correlation of hair C-peptide with nail C-peptide of studied participants. 


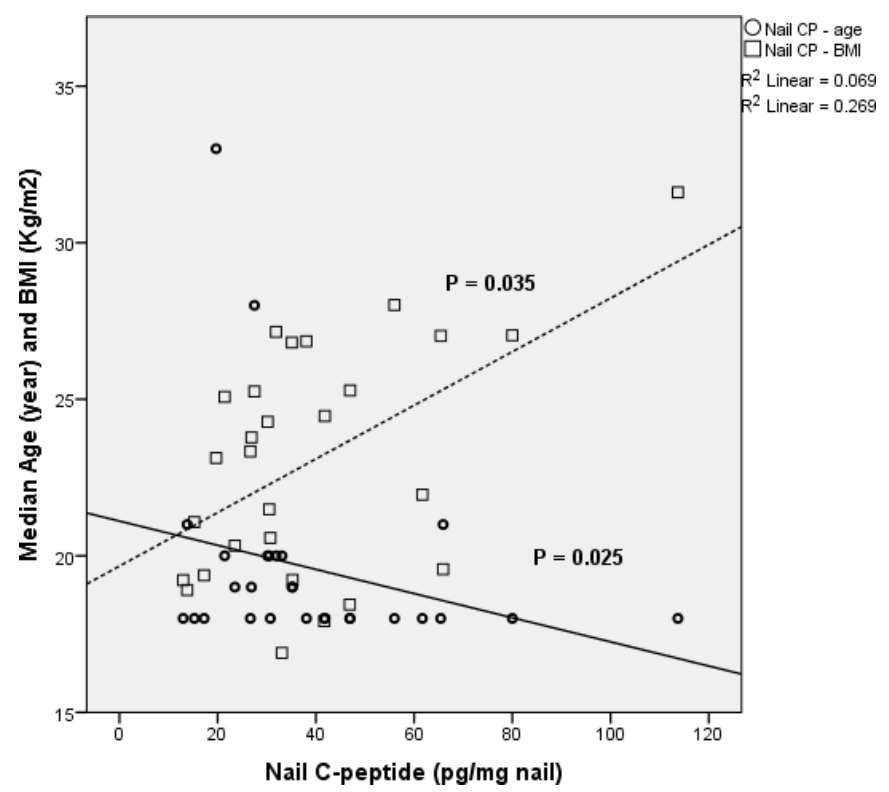

Figure 5 Correlation between nail C-peptide (CP) with age and body mass index (BMI), in the control group. Continuous line-nail CP and age; dotted line-nail CP and BMI.

but not seen in persons with T1DM $(\mathrm{r}=-0.201, \mathrm{p}=0.219)$ (figure 6).

A significantly lower hair and nail C-peptide levels and higher FPG levels were found in subjects with a positive family history of T2DM in their first-degree relatives compared with subjects with a negative family history $(\mathrm{p}<0.05$ as demonstrated in figure 7$)$.

The mean daily insulin dose, measured as unit $/ \mathrm{kg} /$ day, was $1.06(0.35)$. No significant association between daily insulin dose and other variables were found apart from a positive correlation with HbA1c $(\mathrm{r}=0.478, \mathrm{p}=0.007)$.

\section{DISCUSSION}

The basal characteristics of healthy participants and patients with T1DM were compared and both groups

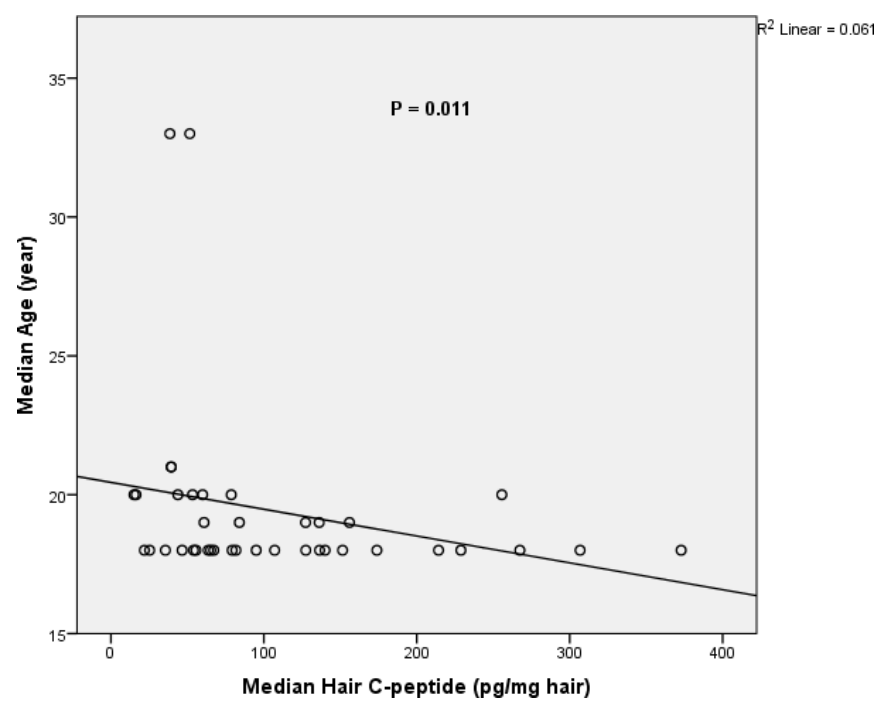

Figure 6 Correlation between hair C-peptide level and age of controlled participants.
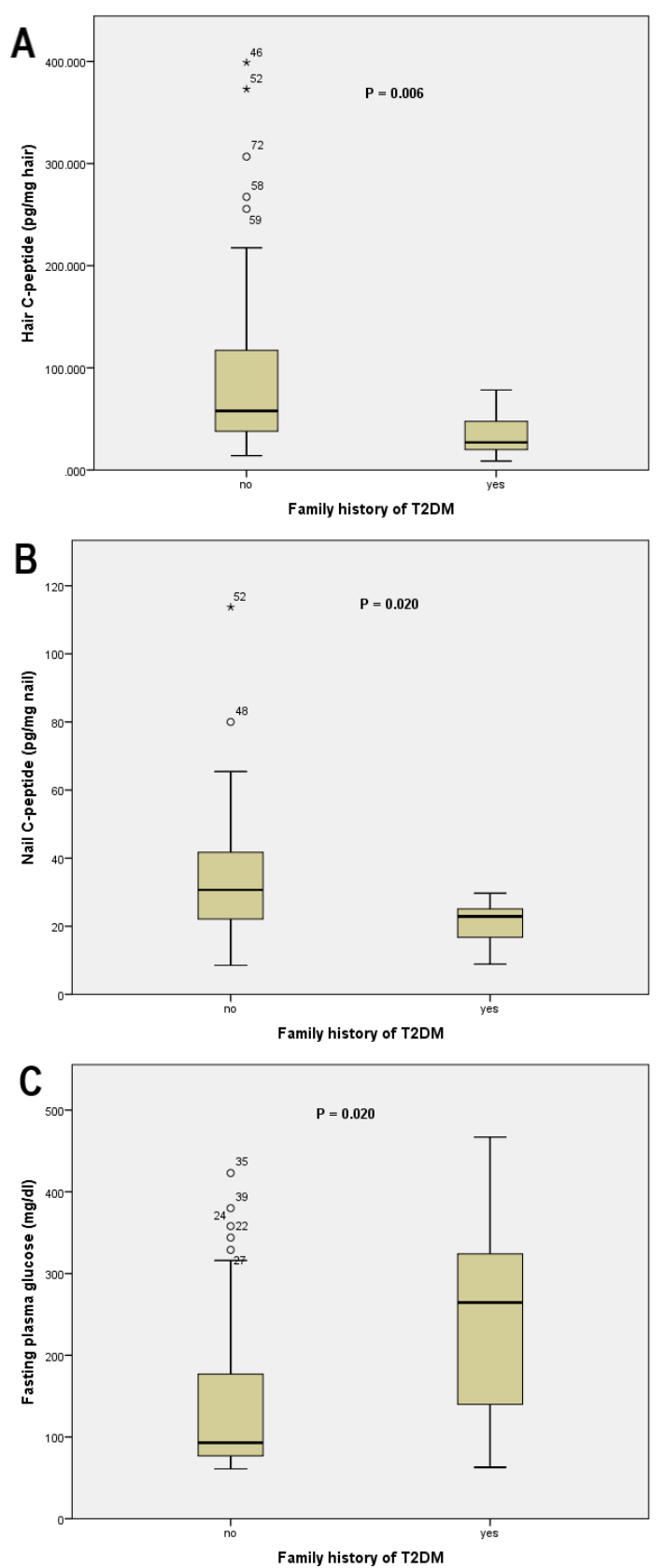

Figure 7 (A) Hair C-peptide (CP), (B) nail CP and (C) fasting plasma glucose in subjects with or without a history of type 2 diabetes mellitus (T2DM) in first-degree relatives. 0 , moderate outlier; ${ }^{*}$, extreme outlier.

were found to be very similar in terms of their age, BMI and waist circumference.

In this study, for the first time alongside a serum specimen, C-peptide levels have been detected in hair and nail samples of healthy adults and patients with T1DM. The mean and median hair C-peptide levels of the control group are comparable with the previous study conducted on hair samples of healthy adults. ${ }^{27}$ It has shown that the median hair C-peptide level in healthy people was twofold greater than the level in patients with T1DM, which was statistically significant. Similarly, a significantly higher median nail C-peptide was recorded in healthy individuals compared with patients with T1DM. Small 
amounts of insulin secretion, reflected by fasting or stimulated C-peptide, were observed in patients with T1DM in the Diabetes Control and Complications Trial and other studies. ${ }^{1329}{ }^{30}$ However, the insulin secretion found in T1DM is insufficient to regulate its metabolic effects and it is much lower than the amount secreted by healthy people. Therefore, subjects with T1DM had significantly higher FPG and HbAlc than normal individuals.

In people with T1DM, the amount of insulin secretion can be affected by the proportion of the remaining $\beta$-cells, the blood glucose concentration and the duration of diabetes. ${ }^{13} 3132$ Our subjects with T1DM were young adults with a short duration of diabetes (mean of 3.3 years), thus it is not surprising for them to secrete small amounts of insulin/C-peptide. Additionally, increased glucose concentration may further stimulate insulin secretion. Thus, the remaining $\beta$-cells in T1DM might be under a relatively stronger glycemia-induced $\beta$-cell stimulation compared with normal people with normoglycemia.

Among the studied participants, hair and nail C-peptide levels are similar between males and females both in healthy persons and persons with T1DM. A previous study showed that although urinary excretion of C-peptide was observed to be similar in both genders, urinary C-peptide creatinine ratio (UCPCR) was higher in females than in males, suggesting that the proportion of muscle mass and creatinine excretion can affect the UCPCR. ${ }^{18}$ Therefore, hair and nail C-peptide levels might not be affected by the difference in the muscle mass as found in UCPCR.

Interestingly, among subjects with T1DM, the serum, nail and hair C-peptide levels were found to be lower in those with a diabetes duration of $\geq 7$ years compared with the levels in patients with a shorter duration. These results are consistent with the studies that concluded there is a progressive loss of the pancreatic $\beta$-cells in T1DM. Importantly, a recent study based on the measurement of UCPCR has suggested that there are two phases of $\beta$-cell destruction: exponential $\beta$-cells lost within the first 7 years of the disease and a subsequent slower decline in $\beta$-cells mass. ${ }^{32} 33$

In the current study, the level of hair C-peptide was found to be significantly higher than nail C-peptide in the control and T1DM groups. This is in line with previous studies that extracted other hormones and found a higher level of the substance in hair than in nail samples. ${ }^{34}$ The reason could be partly related to the difference in the incorporation rate of the circulatory C-peptide into hair and nail tissues and the ability of the methanol to extract the C-peptide from each. Another reason could be due to the difference in the rate of growth between hair and nails, which results in different duration of exposure of these tissues to the interstitial C-peptide. ${ }^{24} 25$

These results showed that the serum C-peptide levels have a significant negative correlation with the duration of diabetes; however, such correlation was not observed with the nail C-peptide or hair C-peptide. This may be caused by prolonged exposure of hair and nail tissues to a minimal circulation of C-peptide compared with the level of serum C-peptide. Serum C-peptide was measured in $\mathrm{ng} / \mathrm{mL}$ while hair and nail C-peptide levels were detected in $\mathrm{pg} / \mathrm{mg}$ of hair and nails, respectively. Therefore, a trace amount of endogenous C-peptide can be incorporated into hair and nail tissues and be detectable but might be measured in serum as $\leq 0.01 \mathrm{ng} / \mathrm{mL}$, as seen in a quarter of cases with T1DM. This may explain why the hair and nail levels of the hormones may not correlate with that of the serum.

Furthermore, we found that hair and nail C-peptide levels had a significantly strong positive correlation. However, neither hair nor nail C-peptide levels were found to be correlated with the fasting serum C-peptide. It is not clear why but it may be due to the hypothesis that each of the hair and nail C-peptide levels represent both basal and prandial insulin secretion. The prandial insulin secretion is around $50 \%$ of the total daily insulin secretion, thus this may explain why hair and nail C-peptide levels are not correlated to that of the fasting serum C-peptide. ${ }^{36}$ Another reason may be due to the point that hair and nail C-peptide levels represent a long-term level compared with the momentary fasting serum C-peptide.

Among the control group, nail C-peptide had a significant negative correlation with age and positive correlation with BMI; hair C-peptide levels significantly decreased with age. Consistent with the previous studies, it is well established that aging-related beta-cell dysfunction can lead to a reduction in insulin production. ${ }^{37}$ Central fat deposition is linked to increased IR, and a healthy pancreas needs to produce larger amounts of insulin to overcome the IR. ${ }^{38}$

Our results also showed that participants having firstdegree relatives with T2DM had significantly lower hair and nail C-peptide levels and higher FPG compared with participants without. This finding is interesting as these participants may have a natural metabolic tendency to develop diabetes; however, our data are not sufficient to suggest that. ${ }^{11}$

Although the range limits of the sample weight were appreciated during sampling, hair and nail C-peptide levels were negatively correlated with their corresponding sample weight. This is in line with the previous study and also necessitates that a similar sample weight of hair and nails should be taken. ${ }^{27}$

This study concludes that C-peptide can be extracted and measured in hair and nail samples of healthy persons and individuals with T1DM. The significantly lower hair and nail C-peptide levels in people with T1DM compared with healthy adults and a significantly lower serum, hair and nail C-peptide levels observed in patients with a diabetes duration of $>7$ years compared with a shorter diabetes duration support the feasibility of C-peptide measurement in hair and nails, in normal persons and in persons with T1DM.

A significantly greater C-peptide level in hair than nail specimens may indicate different incorporation and/or 
extraction rate of C-peptide into and from these tissues and their different growth rate. Interestingly, hair and nail C-peptide levels had a significantly positive correlation. However, neither hair nor nail C-peptide levels were found to be correlated with the fasting serum C-peptide, which might be related to hair and nail C-peptide levels that indicate long-term insulin secretion, including both basal and prandial insulin peaks when compared with fasting C-peptide. Among the control group, nail C-peptide has a significant negative correlation with age and a positive correlation with BMI. Our results suggest that hair and nail C-peptide levels can be a valid measurement of long-term insulin secretion in healthy persons and persons with T1DM.

Although the current study is, for the first time, a measurement of nail and hair C-peptide levels in healthy persons and subjects with T1DM and has found an interesting correlation between hair and nail C-peptide levels with other relevant parameters, there are few limitations. First, we did not obtain stimulated or urinary C-peptide to be compared with hair and nail C-peptide levels. Second, our study subjects were relatively young and has relatively short duration of diabetes.

More research is needed to validate hair and nail C-peptide levels and set the normal limits by including a large sample size with multiethnic and multinational diversity. Further studies are required to also include people with prediabetes, T2DM and the observation of long-term endogenous insulin secretion reflected by the hair and nail C-peptide levels and a prediction of future T2DM among those with prediabetes and future needs of insulin management in patients with overt T2DM. Studying the link between long-term C-peptide, glycemic variability and complications appear to be interesting and clinically implemented. Future studies can link nail and hair C-peptide levels to the diseases associated with IR, like metabolic syndrome, polycystic ovarian syndrome, cardiovascular disease and non-alcoholic steatohepatitis. Future work should maximize the preserved pancreatic $\beta$-cells and may use hair and/or nail C-peptide levels as additional measurements to indicate $\beta$-cell activity.

Acknowledgements The authors would like to thank Nakhshin Abdulla; the Lab chemist at Diabetes and Endocrine center, Sulaimaniyah city and all the staff in Saman Lab, Sulaymaniyah, Iraq for helping in this study.

Contributors JMS and DSA both contributed to the concept and design of the study, and both participated in the data acquisition. DSA performed the data analysis. JMS drafted the manuscript. Both authors interpreted the results, and reviewed the final manuscript before submission. DSA is the guarantor of this work and, had full access to all the data in the study and takes responsibility for the integrity of the data and the accuracy of the data analysis.

Funding The authors have not declared a specific grant for this research from any funding agency in the public, commercial or not-for-profit sectors.

Competing interests None declared.

Patient consent for publication Not required

Ethics approval The study was approved by the College of Medicine-Ethical Committee at the University of Sulaimani located in Sulaymaniyah, Iraq at July 2019, with the Committee meeting number 44. All participants signed the written informed consent before participation in the study.
Provenance and peer review Not commissioned; externally peer reviewed.

Data availability statement Data are available on reasonable request. The datasets generated and analyzed during the current study are available from the corresponding author (DSA, email: darya.abdulateef@univsul.edu.iq) on reasonable request.

Open access This is an open access article distributed in accordance with the Creative Commons Attribution Non Commercial (CC BY-NC 4.0) license, which permits others to distribute, remix, adapt, build upon this work non-commercially, and license their derivative works on different terms, provided the original work is properly cited, appropriate credit is given, any changes made indicated, and the use is non-commercial. See: http://creativecommons.org/licenses/by-nc/4.0/.

ORCID iD

Darya S Abdulateef http://orcid.org/0000-0001-6516-8611

\section{REFERENCES}

1 Horwitz DL, Starr JI, Mako ME, et al. Proinsulin, insulin, and Cpeptide concentrations in human portal and peripheral blood. J Clin Invest 1975;55:1278-83.

2 Palmer JP, Fleming GA, Greenbaum CJ, et al. C-Peptide is the appropriate outcome measure for type 1 diabetes clinical trials to preserve beta-cell function: report of an ADA workshop, 21-22 October 2001. Diabetes 2004;53:64.

3 Bonser AM, Garcia-Webb P. C-Peptide measurement and its clinical usefulness: a review. Ann Clin Biochem 1981;18:200-6.

4 Chitturi S, Abeygunasekera S, Farrell GC, et al. Nash and insulin resistance: insulin hypersecretion and specific association with the insulin resistance syndrome. Hepatology 2002;35:373-9.

$5 \mathrm{Xu} \mathrm{J}, \mathrm{Ye} \mathrm{Y,} \mathrm{Wu} \mathrm{H}$, et al. Association between markers of glucose metabolism and risk of colorectal cancer. BMJ Open 2016;6:e011430.

6 Irwin ML, Duggan C, Wang C-Y, et al. Fasting C-peptide levels and death resulting from all causes and breast cancer: the health, eating, activity, and lifestyle study. J Clin Oncol 2011;29:47-53.

$7 \mathrm{Ma} \mathrm{J}$, Li H, Giovannucci E, et al. Prediagnostic body-mass index, plasma C-peptide concentration, and prostate cancer-specific mortality in men with prostate cancer: a long-term survival analysis. Lancet Oncol 2008;9:1039-47.

8 Duggan C, Irwin ML, Xiao L, et al. Associations of insulin resistance and adiponectin with mortality in women with breast cancer. $J$ Clin Oncol 2011;29:32-9.

9 Jones AG, Hattersley AT. The clinical utility of C-peptide measurement in the care of patients with diabetes. Diabet Med 2013;30:803-17.

10 CHRISTENSEN MB, GOTFREDSEN A, NØRGAARD K. C-Peptide levels are associated with glycemic variability and hypoglycemia in insulin-treated type 2 diabetes. Diabetes 2018;67:398-P.

11 Butler AE, Galasso R, Meier JJ, et al. Modestly increased beta cell apoptosis but no increased beta cell replication in recent-onset type 1 diabetic patients who died of diabetic ketoacidosis. Diabetologia 2007;50:2323-31.

12 Zaccardi F, Webb DR, Yates T, et al. Pathophysiology of type 1 and type 2 diabetes mellitus: a 90-year perspective. Postgrad Med J 2016;92:63-9.

13 Anon. Effects of age, duration and treatment of insulin-dependent diabetes mellitus on residual beta-cell function: observations during eligibility testing for the diabetes control and complications trial (DCCT). The DCCT Research Group. J Clin Endocrinol Metab 1987;65:30-6.

14 Gjessing HJ, Matzen LE, Faber OK, et al. Fasting plasma C-peptide, glucagon stimulated plasma C-peptide, and urinary C-peptide in relation to clinical type of diabetes. Diabetologia 1989;32:305-11.

15 Greenbaum CJ, Mandrup-Poulsen T, McGee PF, et al. Mixed-Meal tolerance test versus glucagon stimulation test for the assessment of beta-cell function in therapeutic trials in type 1 diabetes. Diabetes Care 2008;31:1966-71.

16 Mirel RD, Ginsberg-Fellner F, Horwitz DL, et al. C-Peptide reserve in insulin-dependent diabetes. Comparative responses to glucose, glucagon and tolbutamide. Diabetologia 1980;19:183-8.

17 McDonald TJ, Knight BA, Shields BM, et al. Stability and reproducibility of a single-sample urinary C-peptide/creatinine ratio and its correlation with $24-\mathrm{h}$ urinary $\mathrm{C}$-peptide. Clin Chem 2009;55:2035-9.

18 Thomas NJ, Shields BM, Besser REJ, et al. The impact of gender on urine C-peptide creatinine ratio interpretation. Ann Clin Biochem 2012;49:363-8. 
19 Sauvé B, Koren G, Walsh G, et al. Measurement of cortisol in human hair as a biomarker of systemic exposure. Clin Invest Med 2007;30:183-91.

20 Zgaga L, Laird E, Healy M. 25-Hydroxyvitamin D measurement in human hair: results from a proof-of-concept study. Nutrients 2019;11:423.

21 Davison B, Singh GR, Oguoma VM, et al. Fingernail cortisol as a marker of chronic stress exposure in Indigenous and non-Indigenous young adults. Stress 2020;23:298-307:298-307.

22 Doan SN, DeYoung G, Fuller-Rowell TE, et al. Investigating relations among stress, sleep and nail cortisol and DHEA. Stress 2018;21:188-93.

23 Abdulateef DS, Mahwi TO. Assessment of hair cortisol in euthyroid, hypothyroid, and subclinical hypothyroid subjects. Endocrine 2019;63:131-9.

24 LeBeau MA, Montgomery MA, Brewer JD. The role of variations in growth rate and sample collection on interpreting results of segmental analyses of hair. Forensic Sci Int 2011;210:110-6.

25 Palmeri A, Pichini S, Pacifici R, et al. Drugs in nails. Clin Pharmacokinet 2000;38:95-110.

26 Yaemsiri S, Hou N, Slining MM, et al. Growth rate of human fingernails and toenails in healthy American young adults. J Eur Acad Dermatol Venereol 2010;24:420-3.

27 Abdulateef DS, Salih JM. Detection of C-peptide in scalp hair of healthy adults. Diabetes Metab Syndr Obes 2020;13:227-36.

28 Meyer J, Novak M, Hamel A, et al. Extraction and analysis of cortisol from human and monkey hair. J Vis Exp 2014;50882:e50882.

29 Oram RA, Rawlingson A, Shields BM, et al. Urine C-peptide creatinine ratio can be used to assess insulin resistance and insulin production in people without diabetes: an observational study. BMJ Open 2013;3:e003193.
30 McGee P, Steffes M, Nowicki M, et al. Insulin secretion measured by stimulated C-peptide in long-established Type 1 diabetes in the Diabetes Control and Complications Trial (DCCT)/ Epidemiology of Diabetes Interventions and Complications (EDIC) cohort: a pilot study. Diabet Med 2014;31:1264-8.

31 Kuhtreiber WM, Washer SLL, Hsu E, et al. Low levels of C-peptide have clinical significance for established type 1 diabetes. Diabet Med 2015;32:1346-53.

32 Davis AK, DuBose SN, Haller MJ, et al. Prevalence of detectable C-peptide according to age at diagnosis and duration of type 1 diabetes. Diabetes Care 2015;38:476-81.

33 Shields BM, McDonald TJ, Oram R, et al. C-Peptide decline in type 1 diabetes has two phases: an initial exponential fall and a subsequent stable phase. Diabetes Care 2018;41:1486-92.

34 Voegel C-D, La Marca-Ghaemmaghami P, Hofmann M, et al. Endogenous steroid profiling in hair and nails with a newly developed LC-MS/MS method. Toxicol Anal Clin 2019;31:S23-4.

35 Nejad JG, Ghaseminezhad M, Sung K-I, et al. A cortisol study; facial hair and nails. J Steroids Horm Sci 2016;7:2.

36 Mayfield JA, White RD. Insulin therapy for type 2 diabetes: rescue, augmentation, and replacement of beta-cell function. Am Fam Physician 2004;70:489-500.

37 Yates AP, Laing I. Age-Related increase in haemoglobin A1c and fasting plasma glucose is accompanied by a decrease in beta cell function without change in insulin sensitivity: evidence from a cross-sectional study of hospital personnel. Diabet Med 2002;19:254-8.

38 Tong J, Fujimoto WY, Kahn SE, et al. Insulin, C-peptide, and leptin concentrations predict increased visceral adiposity at 5- and 10 -year follow-ups in nondiabetic Japanese Americans. Diabetes 2005;54:985-90. 